\title{
Costs of the use of carbetocin in the prevention of uterine atony following delivery of the infant by Caesarean section — retrospective multicenter study
}

\author{
Maciej Sobkowski ${ }^{1,2}$, Zbigniew Celewicz ${ }^{3}$, Jarosław Kalinka, ${ }^{4}$, Krzysztof Szymanowski ${ }^{1,2}$, \\ Marcin Serafin ${ }^{5}$, Katarzyna Śmieja ${ }^{3}$, Anna Grzymała-Figura ${ }^{3}$, Kinga Pacocha ${ }^{6}$, \\ Izabela Pieniążek ${ }^{6}$, Jacek Walczak ${ }^{6}$, Agnieszka Żyła ${ }^{6}$, Adam Bierut ${ }^{7}$ \\ ${ }^{1}$ Gynecological and Obstetrics Clinical Hospital of Poznan Medical Science University, Poland \\ ${ }^{2}$ Department of Mother and Child Health, University of Medical Sciences, Poznan, Poland \\ ${ }^{3}$ Department of Perinatology, Obstetrics and Gynecology, Pomeranian Medical University in Szczecin, Poland \\ ${ }^{4}$ Department of Perinatology, Medical University of Lodz, Poland \\ ${ }^{5}$ Pirogowa Regional Specialized Hospital in Lodz, Poland \\ ${ }^{6}$ Arcana Institute, Krakow, Poland \\ ${ }^{7}$ Ferring Pharmaceuticals Poland
}

\begin{abstract}
Objectives: The aim of this study was to compare the costs of using carbetocin in the prevention of uterine atony following delivery of the infant by Caesarean section (C-section) under epidural or spinal anesthesia with standard methods of prevention (SMP).

Material and methods: This retrospective multicenter study was based on data from three medical centers. A questionnaire was developed to gather patient records on consumption and costs of resources related to $\mathrm{C}$-section, prevention of uterine atony and postpartum hemorrhage (PPH) treatment. Six subpopulations were considered, depending on patient characteristics. The analysis covered two perspectives: that of the hospital and of the public payer.

Results: The subpopulations were homogenous, which was a premise for pooling the data. The use of carbetocin in the prevention of uterine atony following Caesarean section generates savings for hospital in comparison with SMP (oxytocin) in 5 of 6 subpopulations. The biggest savings were observed amongst patients who experienced severe PPH and reached 2.6-6.2 thousand PLN per patient. Costs of services related to C-section borne by the hospitals were higher than the refund received from a public payer. The greatest underestimation reached 12.1 thousand PLN per patient. Nevertheless, loss generated by this underfunding was lower in carbetocin versus oxytocin group.

Conclusions: The use of carbetocin instead of SMP gives hospitals an opportunity to make savings as well as to reduce losses resulting from the underfunding of the services provided by the National Health Fund.
\end{abstract}

Key words: carbetocin, postpartum hemorrhage, uterine atony, costs

Ginekologia Polska 2016; 87, 9: 621-628

\section{INTRODUCTION}

Uterine atony is the most frequent cause of $\mathrm{PPH}$ (postpartum hemorrhage) [1-5]. PPH may be also caused by placenta-related factors, blood clotting problems and trauma-related factors [6]. Postpartum hemorrhage is listed as one of the main reasons for maternal perinatal mortal- ity, both in Poland and abroad [2-5, 7]. Excessive bleeding causes symptoms such as light-headedness and dizziness, fainting and/or hypervolemia symptoms (for example, hypotension, tachycardia and oliguria) [2]. In accordance with the Rekomendacje Polskiego Towarzystwa Ginekologicznego dotyczące opieki okołoporodowej i prowadzenia porodu (Pol- 
ish Gynaecological Society Guidelines on perinatal care and delivery management) [9], oxytocin is the first-line contraction-inducing drug in uterine atony prevention. Since 2007, carbetocin has been available on the Polish pharmaceutical market, with indication for uterine atony prevention following $\mathrm{C}$-section childbirth conducted under regional block anesthesia. Carbetocin is an oxytocin analogue with pharmacological and clinical properties of a long-acting oxytocin agonist. Uterine contraction following delivery starts very fast; steady contraction is obtained within 2 minutes. A single dose administered following the extraction of the infant is sufficient to maintain adequate uterine contraction, thus preventing uterine atony and excessive bleeding [10]. The Team of Experts of the Polish Gynecological Society opines that carbetocin is an effective therapeutic option in the prevention and treatment of postpartum hemorrhage following a C-section and its negative effects, and should be available at any delivery and operation room [7].

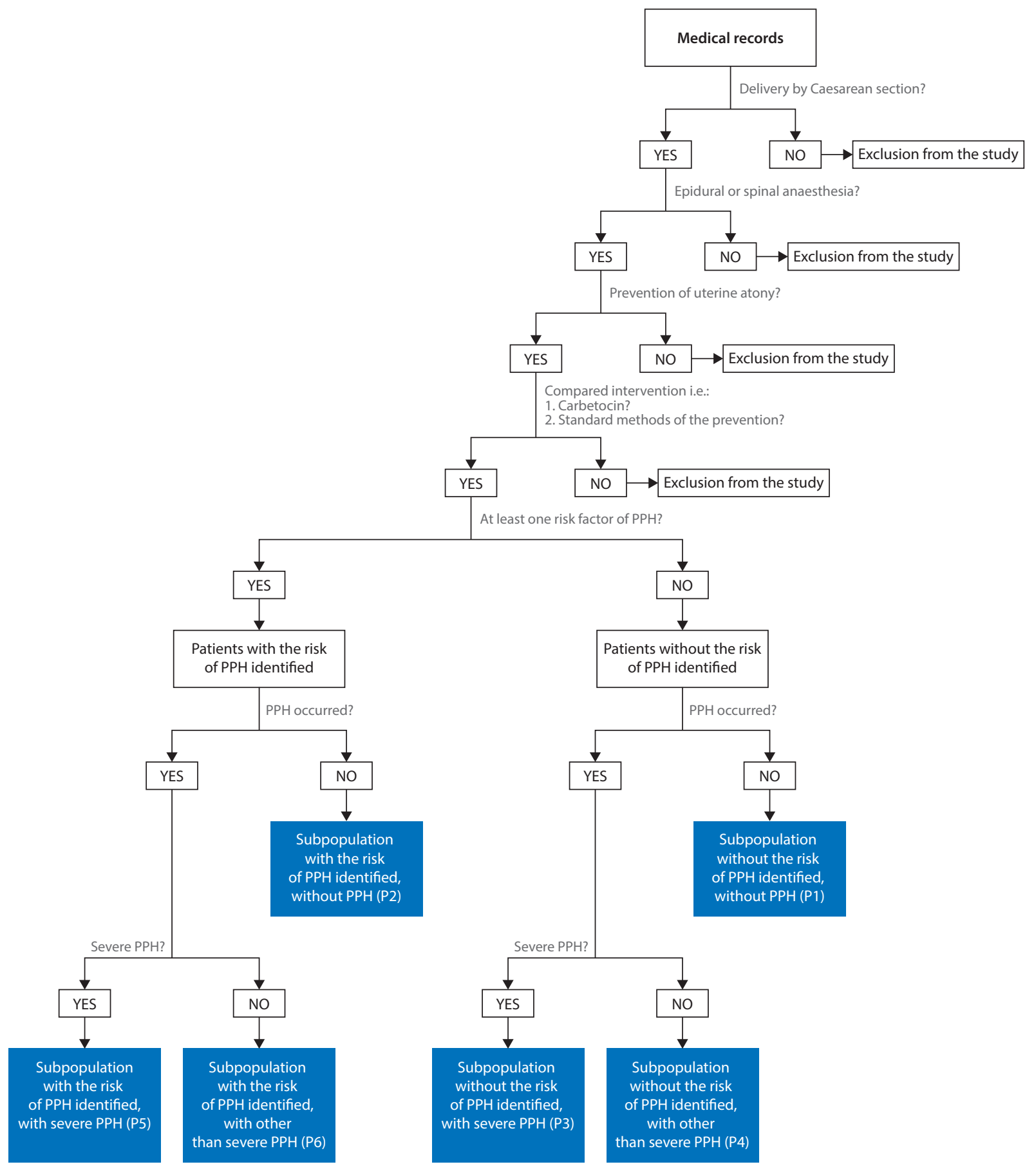

Figure 1. Scheme of the medical cards qualification 


\section{OBJECTIVES}

The aim of the study was to compare the costs of the prevention of uterine atony following a C-section childbirth conducted under regional block anesthesia with the use of carbetocin or standard methods of prevention (SMP). Furthermore, the valuation of groups and procedures within the Diagnosis-related Groups (DRG) system was compared with the costs borne by the service providers. The cost of procedures undertaken in the case of postpartum hemorrhage was estimated as well.

\section{MATERIAL AND METHODS}

A restrospective study of women who gave birth by a Caesarean section conducted under regional block anesthesia, in whom uterine atony was prevented with the use of carbetocin or SMP, was carried out. Taking into account the varied clinical practice in the centers included in the study, among the SMP of uterine atony there was oxytocin as well as other uterotonic drugs (other than carbetocin) used in a given center. An assessed intervention was the administration of $100 \mu \mathrm{g}$ carbetocin in the form of injection solution. Three tertiary care centers participated in the study. The data were obtained from randomly chosen patient medical cards and were collected independently by each of the centers in a specially designed questionnaire, which was validated before the launch of the survey. The process of patient medical card identification is presented in Figure 1. In order to obtain the most current data, the process began with medical cards of patients hospitalized most recently. Six subpopulations were identified with respect to the identified risk of postpartum hemorrhage and its type (severe or other than severe) (Tab. 1). The risk of postpartum hemorrhage was defined as the presence of at least one of the following criteria: placenta previa, premature abruption of the placenta, multiple pregnancy, previous C-section, assessed high fetal weight, polyhydramnios, multiple previous births, atonic bleeding following previous deliveries, uterine fibroids, induced/prolonged delivery and others (details in

\begin{tabular}{|c|c|c|c|}
\hline \multicolumn{3}{|c|}{ Table 1. Subpopulations included in the study } \\
\hline Subpopulation & $\begin{array}{c}\text { Identified } \\
\text { risk of PPH }\end{array}$ & $\begin{array}{c}\text { Type of } \\
\text { observed PPH }\end{array}$ & $\begin{array}{c}\text { Number } \\
\text { of patient } \\
\text { medical cards }\end{array}$ \\
\hline P1 & No & None & 73 \\
\hline P2 & Yes & None & 70 \\
\hline P3 & No & Severe & 22 \\
\hline P4 & No & $\begin{array}{c}\text { Other } \\
\text { than severe }\end{array}$ & 34 \\
\hline P5 & Yes & Severe & 33 \\
\hline P6 & Yes & $\begin{array}{c}\text { Other } \\
\text { than severe }\end{array}$ & 43 \\
\hline
\end{tabular}

Tab. 5). The occurrence of severe PPH was defined as the loss of $>20 \%$ of blood volume within 24 hours after the delivery or speedy loss of over $1000 \mathrm{ml}$ of blood, while the occurrence of PPH other than severe was defined as the loss of $<20 \%$ of blood volume within 24 hours after the delivery or speedy loss of $750-1000 \mathrm{~mL}$ of blood.

In the survey, the following data were obtained:

- characteristics of the centers participating in the study;

- characteristics of each of the subpopulations considered;

- unit costs from the perspective of the service provider: compared interventions, other uterotonic drugs, medicines/medicinal products used in PPH treatment, examinations and procedures related to PPH treatment, patient's stay in a hospital ward, newborn's stay in a hospital ward, treatment of the most frequently reported adverse events related to intervention (carbetocin, SMP), delivery by Caesarean section (excluding costs of uterine atony prevention, costs of adverse events and costs of $\mathrm{PPH}$ treatment), medical staff remunerations;

- utilization of the resources under consideration (the assessed interventions, time spent by the medical staff with the patient in connection with the preventive administration of a uterotonic drug, other uterotonic drugs, drugs/medicinal products as part of PPH treatment, examinations and procedures as part of $\mathrm{PPH}$ treatment, length of a patient's stay in hospital wards due to PPH treatment, time spent by the medical staff with the newborn, length of a newborn's stay in hospital wards);

- number of the most frequently reported adverse events related to the uterine atony prevention method used;

- cost of the hospitalization of patients from the analyzed subpopulations (from the perspective of the service provider).

In order to determine whether the characteristics of patients from the identified subpopulations are balanced between the compared therapeutic measures (carbetocin vs. SMP), a statistical analysis was conducted. Furthermore, a synthesis of the characteristics of patients from all the centers was conducted, as the meta-analysis.

\section{RESULTS}

A total of 275 medical records of patients who gave birth by Caesarean section conducted under regional block anesthesia were included in the study (135 patient medical records involving carbetocin and 140 records involving $\mathrm{SMP}$ ). Based on the predefined criteria, the patients were assigned to six subpopulations (P1-P6). Data on the number of medical cards in each particular subpopulation are presented in Table 2.

In accordance with the research, C-section is conducted in the case of $48 \%$ deliveries. Almost $99 \%$ of Caesarean sections 
Table 2. The number of medical records included in the study

\begin{tabular}{|l|c|c|c|c|c|c|}
\hline & P1 & P2 & P3 & P4 & P5 & P6 \\
\hline Center I & 20 & 20 & 1 & 13 & 6 & 20 \\
\hline Center II & 20 & 20 & 20 & 20 & 20 & 20 \\
\hline Center III & 33 & 30 & 1 & 1 & 7 & 3 \\
\hline In total & 73 & 70 & 22 & 34 & 33 & 43 \\
\hline
\end{tabular}

are performed under regional block anesthesia. Oxytocin is a standard method of uterine atony prevention used in the centers. In 2 out of 3 centers, carbetocin is administered primarily to patients at risk of postpartum hemorrhage. Detailed information concerning the characteristics of the centers participating in the study is presented in Table 3.

Based on the conducted statistical analysis of data concerning patient age and the number of deliveries per patient, in the majority of the subpopulations no statistically significant differences between patients who received carbetocin/SMP as uterine atony prevention were found. Only in Center III, the mean age of the patients from subpopulations P1 and P2 was significantly higher in the case of carbetocin treatment, while in Center I the mean number of deliveries per patient was significantly higher in the case of patients from subpopulation P2 who received SMP. Detailed information on the patients' age and the number of deliveries in particular subpopulations is presented in Table 4.

In the case of most parameters concerning the risk factors for $\mathrm{PPH}$ recorded in subpopulations $\mathrm{P} 2, \mathrm{P} 5$ and $\mathrm{P} 6$ included in the study, no significant differences were observed between the compared methods of treatment (carbetocin vs. SMP). The only significant difference was found in the Center III in the subpopulation P2 for induced delivery/prolonged delivery,

\begin{tabular}{|c|c|c|c|}
\hline Parameter & Center I & Center II & Center III \\
\hline Total number of deliveries in the center per year & 2,200 & $1,470-1,737$ & 7,093 \\
\hline $\begin{array}{l}\text { Number of deliveries ending with a C-section } \\
\text { in a year }(\%)\end{array}$ & $1,175(53 \%)$ & $758-861(52-50 \%)$ & $2,890(41 \%)$ \\
\hline $\begin{array}{l}\text { Percentage of C-sections conducted under } \\
\text { regional block anesthesia }\end{array}$ & $99.5 \%$ & $98-99 \%$ & $98.27 \%$ \\
\hline Carbetocin use & $\begin{array}{l}\text { Following doctor's decision, } \\
\text { unlimited }\end{array}$ & Unlimited & $\begin{array}{l}\text { Following doctor's decision, } \\
\text { unlimited* }\end{array}$ \\
\hline Standard preventative methods (SMP) & $\begin{array}{l}10 \text { units of oxytocin (without } \\
\text { dissolving in infusion liquid) } \\
\text { administered directly to the } \\
\text { uterine muscle }\end{array}$ & $\begin{array}{l}5 \text { units of oxytocin (without } \\
\text { dissolving in infusion liquid) } \\
\text { administered intravenously }\end{array}$ & $\begin{array}{l}\text { Oxytocin administered } \\
\text { intravenously }\end{array}$ \\
\hline Data report period (carbetocin / SMP) & $2014 / 2013$ & 2014/2010-2011 & $2014 / 2014$ \\
\hline
\end{tabular}

*In 2014 carbetocin was administered to $18.3 \%$ of patients, out of which $72 \%$ were patients at risk of PPH

\begin{tabular}{|c|c|c|c|c|c|c|c|c|}
\hline Parameter & Center & Intervention & P1 & P2 & P3 & P4 & P5 & P6 \\
\hline \multirow{6}{*}{$\begin{array}{l}\text { Mean patient age } \\
\text { (SD) (years) }\end{array}$} & \multirow{2}{*}{1} & Carbetocin & $32.1(6.59)$ & $29.8(7.78)$ & 41 & $33(6.02)$ & 30.33 & 32.5 (9.09) \\
\hline & & SMP & $29.9(4.92)$ & $31.3(5.87)$ & - & $32(7.17)$ & - & $31.4(1.97)$ \\
\hline & \multirow{2}{*}{ II } & Carbetocin & $29.2(5.55)$ & $29.3(6.51)$ & $30.1(4.86)$ & $30.1(6.14)$ & $32.3(5.17)$ & $31.1(4.29)$ \\
\hline & & SMP & $30.6(6.88)$ & $30.9(5.30)$ & $27.7(6.62)$ & 30.9 (3.69) & $32(3.29)$ & $32.1(2.58)$ \\
\hline & \multirow{2}{*}{ III } & Carbetocin & $29.7(0.98)^{*}$ & $32(0.61)^{*}$ & 34 & - & $34.2(5.97)$ & $30(5.29)$ \\
\hline & & SMP & $28(1.74)^{*}$ & $29.7(2.37)^{*}$ & - & 29 & $32.5(8.60)$ & 29 \\
\hline \multirow{6}{*}{$\begin{array}{l}\text { Mean number } \\
\text { of deliveries per } \\
\text { patient (SD) }\end{array}$} & \multirow{2}{*}{1} & Carbetocin & $1.6(0.69)$ & $1.4(0.33)^{*}$ & 1 & $1.14(0.46)$ & 2.16 & $1.7(0.67)$ \\
\hline & & SMP & $1.1(0.41)$ & $1.9(0.65)^{*}$ & - & $1.17(0.48)$ & - & $1.9(1.04)$ \\
\hline & \multirow{2}{*}{ II } & Carbetocin & $0.3(1.23)$ & 1.4 (1.76) & $0.2(0.37)$ & 0 & 1.4 (1.76) & $1.2(0.99)$ \\
\hline & & SMP & $0.3(0.78)$ & $0.6(0.33)$ & $0.4(0.75)$ & 1 & $0.7(0.67)$ & $0.9(0.65)$ \\
\hline & \multirow{2}{*}{ III } & Carbetocin & $1.2(0.37)$ & $1.7(0.63)$ & 1 & - & $3.6(1.01)$ & $2(1.32)$ \\
\hline & & SMP & $1.2(0.64)$ & $1.3(0.67)$ & - & 1 & $2(1.32)$ & 1 \\
\hline
\end{tabular}

*Statistically significant difference (carbetocin vs SMP) 
Table 5. The frequency of PPH risk factors among patients in subpopulations P2, P5, P6

\begin{tabular}{|c|c|c|c|c|c|c|}
\hline \multirow[b]{2}{*}{ PPH risk factor } & \multicolumn{2}{|c|}{ P2 } & \multicolumn{2}{|c|}{ P5 } & \multicolumn{2}{|c|}{ P6 } \\
\hline & $\begin{array}{l}\text { Carbetocin } \\
\qquad \begin{array}{c}(\mathrm{N}=33) \\
n(\%)\end{array}\end{array}$ & $\begin{array}{c}\text { SMP } \\
\left(\begin{array}{c}N=37) \\
n(\%)\end{array}\right.\end{array}$ & $\begin{array}{l}\text { Carbetocin } \\
\qquad \begin{array}{c}(\mathrm{N}=15) \\
\mathrm{n}(\%)\end{array}\end{array}$ & $\begin{array}{c}\text { SMP } \\
(N=12) \\
n(\%)\end{array}$ & $\begin{array}{l}\text { Carbetocin } \\
\qquad \begin{array}{c}(\mathrm{N}=22) \\
\mathrm{n}(\%)\end{array}\end{array}$ & $\begin{array}{c}\text { SMP } \\
(N=21) \\
n(\%)\end{array}$ \\
\hline Placenta previa & $2(6.06)$ & $0(0.00)$ & $4(26.67)$ & $1(8.33)$ & $2(9.09)$ & $0(0.00)$ \\
\hline Placental abruption & $2(6.06)$ & $0(0.00)$ & $2(13.33)$ & $1(8.33)$ & $3(13.64)$ & $1(4.76)$ \\
\hline Previous Caesarean section & $16(48.48)$ & $18(48.65)$ & $12(80.00)$ & $8(66.67)$ & $7(31.82)$ & $9(42.86)$ \\
\hline Multiple pregnancy & $4(12.2)$ & $0(0.00)$ & $1(6.67)$ & $3(25.00)$ & $5(22.73)$ & $5(23.81)$ \\
\hline Assessed high fetal weight & $1(3.03)$ & $3(8.11)$ & $0(0.00)$ & $1(8.33)$ & $0(0.00)$ & $1(4.76)$ \\
\hline Hydramnios & $1(3.03)$ & $1(2.70)$ & $0(0.00)$ & $0(0.00)$ & $1(4.55)$ & $0(0.00)$ \\
\hline Induced/prolonged delivery & $4(12.12)$ & $12(32.43)$ & $0(0.00)$ & $0(0.00)$ & $5(22.73)$ & $3(14.29)$ \\
\hline Grand multipara & $1(3.03)$ & $2(5.41)$ & $5(33.33)$ & $0(0.00)$ & $0(0.00)$ & $0(0.00)$ \\
\hline Bicornuate uterus & $0(0.00)$ & $0(0.00)$ & $1(6.67)$ & $0(0.00)$ & $0(0.00)$ & $0(0.00)$ \\
\hline Uterus didelphys & $0(0.00)$ & $1(2.70)$ & $0(0.00)$ & $0(0.00)$ & $0(0.00)$ & $0(0.00)$ \\
\hline Uterine fibroids & $1(3.03)$ & $0(0.00)$ & $0(0.00)$ & $0(0.00)$ & $2(9.09)$ & $0(0.00)$ \\
\hline Premature birth & $2(6.06)$ & $0(0.00)$ & $0(0.00)$ & $0(0.00)$ & $0(0.00)$ & $2(9.52)$ \\
\hline Thrombophilia & $1(3.03)$ & $0(0.00)$ & $0(0.00)$ & $0(0.00)$ & $1(4.55)$ & $0(0.00)$ \\
\hline Obesity & $1(3.03)$ & $0(0.00)$ & $0(0.00)$ & $0(0.00)$ & $1(4.55)$ & $0(0.00)$ \\
\hline
\end{tabular}

more frequently noted in the group of patients in whom SMP were used for uterine atony. However, following the meta-analysis, no statistically significant differences were found between the groups (carbetocin vs. SMP) with respect to the frequency of PPH risk factors in subpopulations P2, P5 and P6. Data on the frequency of PPH risk factors in subpopulations P2, P5 and P6 are summarized in Table 5.

To sum up, it has to be concluded that subpopulations P1-P6 analyzed in the study are homogenous in their general characteristics and with respect to the frequency of particular PPH risk factors. The abovementioned conclusion allows for the synthesis of the data obtained from all the centers for each of the considered subpopulations.

The cost analysis was based on the data provided by researchers concerning the unit costs and the utilization of resources. In view of the homogeneity of the subpopulations considered, an averaged hospitalization cost for all the three centers was estimated for each patient from subpopulations $\mathrm{P} 1-\mathrm{P} 6$ receiving uterine atony preventive treatment with carbetocin/SMP. The use of carbetocin in uterine atony prevention following a Caesarean section and the utilization of related resources incurs lower costs to the hospital than the use of SMP in 5 out of 6 subpopulations analyzed (Fig. 2). The greatest cost savings resulting from the use of carbetocin were observed in subpopulations $\mathrm{P} 3$ and $\mathrm{P} 5$, that is, among patients who have experienced severe post-partum hemorrhage. The aforementioned savings amounted to approximately PLN 2,610 and PLN 6,155 per patient from subpopulation P3 and P5, respectively. It was only in subpopulation P2 that higher cost was observed in

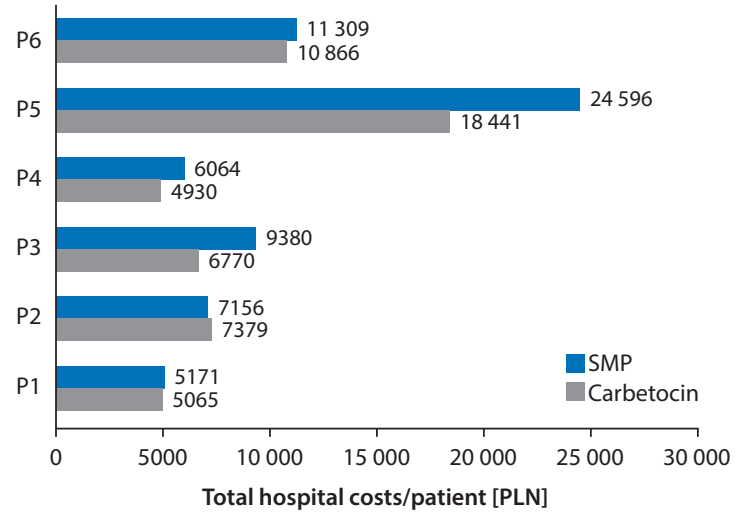

Figure 2. Average total hospital costs per patient — carbetocin vs. SMP

the case of carbetocin use than in the case of SMP, amounting to approximately PLN 224 per patient.

Considering particular categories of resources (Tab. 6), the greatest cost savings to the hospital resulting from the use of carbetocin rather than SMP were observed with respect to other medication (other than uterotonic) and medical procedures used in PPH treatment (savings in the range of PLN 62-2,997 per patient from subpopulation P3-P6), as well as with respect to the stay of the newborn in a hospital ward (savings in 5 out of 6 subpopulations in the range of PLN 212-2,080). Additional hospital costs resulting from the use of carbetocin instead of SMP in uterine atony prevention were caused by mainly from the difference in the cost of carbetocin and oxytocin. In none of the studied subpopulations adverse events related to 
Table 6. Mean hospital costs per patient divided into categories of utilized resources - carbetocin vs. SMP*

\begin{tabular}{|c|c|c|c|c|c|c|}
\hline \multirow{2}{*}{ Category } & \multicolumn{6}{|c|}{ Cost differences per patient: carbetocin vs SMP [PLN] } \\
\hline & P1 & $\mathbf{P 2}$ & P3 & P4 & P5 & P6 \\
\hline $\begin{array}{l}\text { Uterine atony prevention - use of the analyzed uterotonic drugs } \\
\text { (carbetocin/oxytocin) }\end{array}$ & 106.59 & 106.62 & 107.82 & 106.98 & 107.40 & 106.98 \\
\hline Uterine atony prevention - use of other uterotonic drugs & -1.17 & -2.83 & 0.29 & -1.44 & 1.43 & 1.96 \\
\hline Uterine atony prevention - AEs related to uterotonic drugs & 0.00 & 0.00 & 0.00 & -2.50 & 0.00 & 0.00 \\
\hline $\mathrm{PPH}$ treatment — use of uterotonic drugs & $\mathrm{n} / \mathrm{a}$ & $\mathrm{n} / \mathrm{a}$ & -9.47 & -17.83 & 0.35 & -63.97 \\
\hline PPH treatment - use of other medicine and medical procedures & $\mathrm{n} / \mathrm{a}$ & $\mathrm{n} / \mathrm{a}$ & -628.42 & -565.88 & $-2,996.87$ & -62.27 \\
\hline PPH treatment - length of a patient's stay in a hospital ward & $\mathrm{n} / \mathrm{a}$ & $\mathrm{n} / \mathrm{a}$ & 0.00 & -13.75 & $-2,025.00$ & 110.78 \\
\hline Newborn's stay in hospital - length of the newborn's stay in a hospital ward & -212.08 & 119.89 & $-2,080.00$ & -640.00 & $-1,242.27$ & -536.49 \\
\hline
\end{tabular}

*Parameters which did not generate differences between the compared: uterine atony prevention — staff time spent/administration, $\mathrm{PPH}$ treatment — staff time spent/PPH, neonatal care - staff time spent/newborn, birth by Caesarean section

Negative values denote cost savings resulting from the use of carbetocin, while positive values indicatean additional cost resulting from its use; $n / a-n o t$ applicable;

AEs - adverse events. Costs were gathered between 2013 and 2014

the use of carbetocin in uterine atony prevention were observed, which points to its favorable safety profile in the analyzed population.

In order to compare the estimated pricing of groups and procedures in the Diagnosis-related Groups (DRG) system with the actual costs incurred by service providers, the hospital costs per patient from subpopulation P1-P6 treated with carbetocin/SMP, averaged for all centers, were used as well as averaged costs per patient from the considered subpopulations from the perspective of the public payer (based on the data obtained from the centers).

The cost of the hospital services rendered was underestimated by the National Health Fund (Fig. 3): in the majority of cases, the cost of the care of a patient subjected to Caesarean section incurred by hospitals exceeded the refund from the National Health Fund (based on the pricing of DRG and medical procedures). The greatest cost underestimation concerns subpopulation P5 (PLN 4,501/per patient with the use of carbetocin, PLN 12,112/per patient with the use of

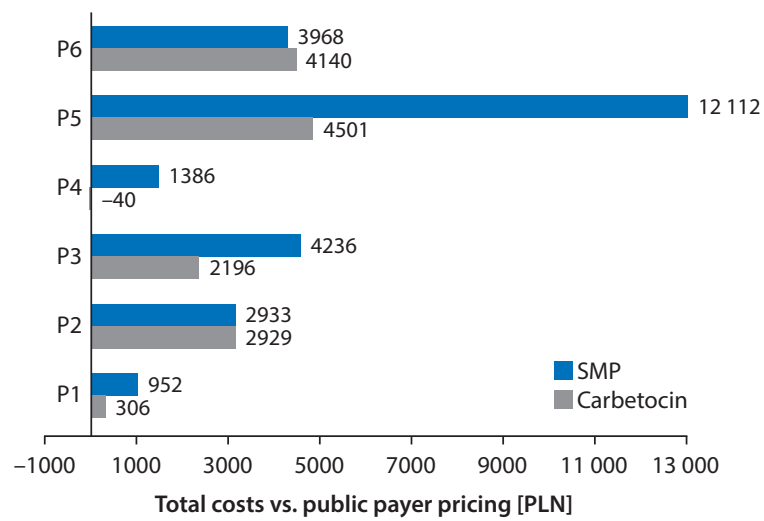

Figure 3. Difference between cost incurred by the hospital vs. public payer pricing of the care of the patient
SMP). Only in the subpopulation P4, in the case of carbetocin use, the National Health Fund's pricing covers the cost of care over the patient incurred by the service provider. In general, by using carbetocin instead of SMP in the uterine atony prevention, the loss incurred by the hospital is decreased by at least PLN 4/per patient from subpopulation $\mathrm{P} 2$ to PLN 2,041/per patient from subpopulation P3 to even PLN 7,610/per patient from subpopulation $P 5$. With respect to settling the cost of services with the National Health Fund, only in subpopulation P6 the use of carbetocin proved less cost-effective than the use of SMP.

The estimation of the average cost of PPH treatment irrespective of the uterine atony prevention method used demonstrated that the treatment of severe postpartum hemorrhage is more than twice as expensive as the treatment of other than severe PPH (Fig. 4). The cost of PPH treatment incurred by the hospital (both severe and other than severe) exceeded the refund obtained from the National Health Fund. The underestimation of the treatment of severe PPH by the National Health Fund amounts, on average, to PLN 5,871, while the treatment of other than se-

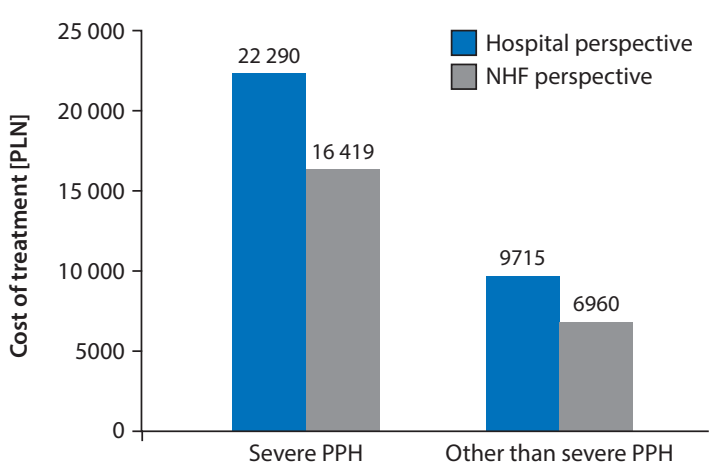

Figure 4. The costs of PPH treatment 
vere PPH amounts to PLN 2,756. Therefore, avoidance of one severe post-partum hemorrhage allows the hospital to avoid a loss of almost PLN 6 thousand caused by the underestimation of the cost of the services by the National Health Fund. On the other hand, avoidance of one other than severe post-partum hemorrhage allows the hospital to avoid a loss of almost PLN 3 thousand in connection with the National Health Fund's underestimation.

\section{DISCUSSION}

In the majority of studies published so far, only the clinical effectiveness of carbetocin was assessed, whereas data on costs are scarce The authors of the abstract Del Angel-Garcia (2006) presented average costs incurred by the Mexican Social Security Institute in connection with the uterine atony preventionusing carbetocin in comparison with oxytocin. The costs per patient from $\mathrm{PHH}$ risk group were estimated on the basis of the average resource utilization and turned out to be lower for carbetocin use by approximately $\$ 529$ (\$3525 vs. \$4054) [11]. By comparison, Higgins et al. estimated that using carbetocin in patients from $\mathrm{PPH}$ low risk group entails a cost higher by $£ 18,51$ than the cost of prevention before the introduction of carbetocin ( $£ 80.21$ vs. $£ 98.73$ ). Calculations were based on a randomized study conducted in Great Britain.The costs considered in the study included cost of staff per minute, cost of analgesics and antiemetics, consumables such as syringes and needles, from the moment of delivery until the transfer of the newborn to the postnatal ward. The main reason for the increase in cost is the price difference between the preparations containing carbetocin and oxytocin (£16.93/patient) [12].

The comparison of the results of our study with the results obtained by Del Angel-Garcia and Higgins et al. is hindered by the fact that the pricing and the manner of settlement of the costs of medical procedures are country(the perspective of the public payer) and center-specific (the perspective of the service provider). So far, no study has been published which would compare the cost of carbetocin use with SMP use in uterine atony in Polish conditions.

While interpreting the results of this study, it has to be kept in mind that it involved three hospitals of tertiary care. Therefore, conclusions drawn from the study consider their characteristics and may be generalized only with respect to centers of this type. The retrospective character of this study results in certain limitations. In our study, the centers did not possess data concerning the utilization of resources for each of the studied therapeutic methods in some subpopulations. Therefore, in the calculation of the averaged cost for all subpopulations in all centers, only data from the centers in which results for both types of intervention considered were included. On the one hand, such an approach narrows down the input data on the basis of which the results were calculated; however, on the other hand, it prevents the error resulting from different pricing characteristic of a given center.

Despite a few limitations, the conducted study allowed the authors to gather information significant from the economic perspective of hospitals which have limited resources at their disposal. It may seem that the additional expenditures connected with the use of carbetocin (the cost of which is higher than the cost of well-known and widely used oxytocin), may constitute a burden for the hospital budget. However, the analysis conducted in different subpopulations and the results of the study indicate different conclusions. In fact, the use of carbetocin contributes to lower resource consumption, which, in turn, causes the decrease in the hospital costs as compared to oxytocin use. The greatest differences were observed among the patients with severe post-partum hemorrhage. Similarly, among the patients who experienced other than severe hemorrhage, the cost in the group in which carbetocin was used was lower than in the group in which oxytocin was administered. Also, the analysis of data connected with the pricing of services by the National Health Fund points to the conclusion that the use of carbetocin is more cost-effective from the perspective of the hospital, as it allows for reducing the loss resulting from the underestimation of the cost of services by the National Health Fund. Currently, under the Regulation of the Minister of Health of 9 November 2015 on the standards of medical procedure (...) in the field of obstetrics and gynecology in perinatal obstetric-gynecological care $(\ldots)^{*}$ carbetocin is recommended in the prevention of perinatal hemorrhage in patients at risk of such a hemorrhage.

\section{CONCLUSIONS}

The use of carbetocin is a safe and highly cost-effective method of perinatal hemorrhage prevention with respect to conventional methods of such prevention. It gives hospitals an opportunity to generate savings or reduce the loss resulting from the cost underestimation by the National Health Fund.

\section{Conflict of interest}

The authors declare that there is no conflict of interest.

\section{REFERENCES}

1. Drews K, Słomko Z, Friebe Z, [et al.]. Atonia macicy. In: Słomko Z, Drews K (eds.). Krwotoki położnicze. Wyd. Lek. PZWL, Warszawa 2010.

2. Jacobs AJ. Causes and treatment of postpartum hemorrhage. UpToDate ${ }^{\circledast}$. http://issuu.com/olinad_2005/docs/causes-and-treatment-of-postpartum-hemorrhage\# (dostęp: 2015.10.06).

\footnotetext{
* Rozporządzenie Ministra Zdrowia z dnia 9 listopada 2015 r. w sprawie standardów postępowania medycznego przy udzielaniu świadczeń zdrowotnych w dziedzinie położnictwa i ginekologii z zakresu okołoporodowej opieki położniczo-ginekologicznej, sprawowanej nad kobietą w okresie ciąży, porodu, połogu, w przypadkach występowania określonych powikłań oraz opieki nad kobietą w sytuacji niepowodzeń położniczych
} 
3. Kalinka J, Lipińska M, Sosnowski D, [et al.]. Ocena skuteczności stosowania karbetocyny w profilaktyce krwawień poporodowych u kobiet po cięciu cesarskim - doniesienie wstępne. Ginekol Pol. 2009, 80, 512-517.

4. Kalinka J, Lipińska M, Serafin M, [et al.]. Ocena skuteczności zastosowania karbetocyny $\left(\mathrm{Pabal}^{\circ}\right) \mathrm{w}$ profilaktyce krwotoków po cięciach cesarskich wykonanych w trybie naglącym - doniesienie wstępne. Gin Pol Med. Project. 2009, 3, 47-56.

5. Oleszczuk J, Leszczyńska-Gorzelak B, Szymula D, [et al.]. Ciężkie krwotoki poporodowe po porodach drogami natury oraz po cięciu cesarskim. Gin Pol Med. Project. 2011, 3, 27-45.

6. Poręba R. Krwotok poporodowy - algorytm postępowania. Ginekologia i Położnictwo. 2006, 1, 7-19.

7. Rozszerzone stanowisko Zespołu Ekspertów Polskiego Towarzystwa Ginekologicznego dotyczące zastosowania karbetocyny w profilaktyce krwotoku poporodowego. Gin Pol Med Project. 2013, 1.
8. Sobieszczyk S, Bręborowicz GH. Rekomendacje postępowania w krwotokach poporodowych. Część I. Protokół postępowania. Kliniczna Perinatologia i Ginekologia. 2004, 40, 60-63.

9. Rekomendacje PTG dotyczące opieki okołoporodowej i prowadzenia porodu. Ginekol Pol. 2009, 80, 548-557.

10. Zespół Ekspertów Polskiego Towarzystwa Ginekologicznego. Stanowisko Zespołu Ekspertów Polskiego Towarzystwa Ginekologicznego dotyczące zastosowania karbetocyny w profilaktyce krwotoku poporodowego. Gin Pol Med Project. 2012, 2.

11. Del Angel-Garcia G, Garcia-Contreras F, Constantino-Casas P, [et al.]. Economic evaluation of carbetocine for the prevention of uterine atony in patients with risk factors in Mexico. Value in Health. 2006, 9, A254.

12. Higgins L, Mechery J, Tomlinson AJ. Does carbetocin for prevention of postpartum haemorrhage at caesarean section provide clinical or financial benefit compared with oxytocin? J. Obstet Gynaecol. 2011, 31, 732-739. 